DIGITAL COMMONS

@ UNIVERSITY OF SOUTH FLORIDA
ABO: Interactive Journal for

Women in the Arts, 1640-1830

\title{
Trading Places: Mary Shelley's Argument with Domestic Space
}

Eve M. Lynch

California State University, East Bay, eve.lynch@csueastbay.edu

Follow this and additional works at: https://digitalcommons.usf.edu/abo

Part of the Dramatic Literature, Criticism and Theory Commons, Educational Methods Commons, Feminist, Gender, and Sexuality Studies Commons, and the Literature in English, British Isles Commons

\section{Recommended Citation}

Lynch, Eve M. (2013) "Trading Places: Mary Shelley's Argument with Domestic Space," ABO: Interactive Journal for Women in the Arts, 1640-1830: Vol.3: Iss.1, Article 2.

http://dx.doi.org/10.5038/2157-7129.3.1.2

Available at: https://digitalcommons.usf.edu/abo/vol3/iss1/2

This Scholarship is brought to you for free and open access by Digital Commons @ University of South Florida. It has been accepted for inclusion in ABO: Interactive Journal for Women in the Arts, 1640-1830 by an authorized administrator of Digital Commons @ University of South Florida. For more information, please contact digitalcommons@usf.edu. 


\title{
Trading Places: Mary Shelley's Argument with Domestic Space
}

\author{
Abstract \\ When Mary Shelley began writing The Last Man in 1824 in the wake of her husband Percy Bysshe \\ Shelley's untimely death, she drew from her close circle of family and friends as models for her main \\ characters. Although it is tempting to view this novel as an autobiographical expiation of the profound \\ sorrow that overwhelmed Shelley at her husband's death, to do so is to underestimate her prescient \\ political insight and to risk overlooking the complex implications of class and rank that suffuse the \\ position of the narrator, Lionel Verney. While Shelley's emotions give a passionate appeal to this novel, her \\ intellectual ideas infuse the novel's powerful critique of British governance. The Last Man is narrated in a \\ political framework in which war and the clash of empires, parliamentary and republican conflict, \\ turbulent revolution, and social and political corruption arrange the fates of the characters. In addition, the \\ plague that silently and invisibly takes over Western Europe and England serves as a spectral process of \\ corrosive malignity from outside, ensnaring all efforts to fix a domestic English system that is collapsing \\ around individuals and the collective.
}

\section{Keywords}

Mary Shelley, The Last Man, 19th-century servants, 19th-century gender politics, 19th-century family, 19thcentury social reform, 19th-century English national identity, 19th-century English civil servant, 19thcentury English public service, master-servant relationship, dystopian novel, Republican motherhood

\section{Creative Commons License} (c) (i) $\odot$

This work is licensed under a Creative Commons Attribution-No Derivative Works 3.0 License. 
When Mary Shelley began writing The Last Man in 1824 in the wake of her husband Percy Bysshe Shelley's untimely death, she drew from her close circle of family and friends as models for her main characters: the noble Adrian who drowns in Italy points to the aggrieved wife's tribute to her drowned husband. The heroic Lord Raymond who gives his life to save Greece from the Turks clearly reflects Lord Byron, who had died in Greece almost immediately after she had begun writing the novel. Although it is tempting to view this novel as an autobiographical expiation of the profound sorrow that overwhelmed Shelley at her husband's death, to do so is to underestimate her prescient political insight and to risk overlooking the complex implications of class and rank that suffuse the position of the narrator, Lionel Verney. While Shelley's emotions give a passionate appeal to this novel, her intellectual ideas infuse the novel's powerful critique of British governance. The Last Man is narrated in a political framework in which war and the clash of empires, parliamentary and republican conflict, turbulent revolution, and social and political corruption arrange the fates of the characters. In addition, the plague that silently and invisibly takes over Western Europe and England serves as a spectral process of corrosive malignity from outside, ensnaring all efforts to fix a domestic English system that is collapsing around individuals and the collective.

That Mary Shelley kept close watch on--and was often enraged at--the ministrations and intrigues of British governmental politics is evident in her many letters sent to friends while she lived abroad with her husband. Side by side with her comments about expatriate friends and visitors, the daily cares of her household and troubled domestic affairs with servants, Mary Shelley writes lengthy commentaries on the government at home and the “despotism” she sees deepening in England's ministry. ${ }^{1}$ In The Last Man she elaborates her most extended vision of the failure of English government to sustain a domestic policy that could serve family and state equitably. For Shelley, the notions of English service--to the family, to the country and government, to the Empire--are plagued with failure because they fundamentally separate men and women from a shared commitment to basic domestic concord and security. In a novel that challenges the boundaries delineating domestic space from national theater, Shelley argues that England faces an unsustainable world of social and political identities untenably shaped by troubled geographies of influence, both domestically and abroad.

Through the servant Lionel Verney, Shelley critiques the idea that the resources of domestic virtue--devotion, trust, loyalty, obedience, and subjection to the good of the whole--can be extracted from the home and instilled in social models that replicate a patriarchal master-servant relationship to elide any egalitarian role for women. Verney becomes the figure who radiates ideals and forms of service that emanate from his outsider status in servitude, a status that adapts to new circumstances because it is not bound by ideologies of the dependent female. Writing about a male servant, rather than the female servant who was replacing him historically in English domestic life, allows Shelley to align what she sees as the male desertion of the home with a universalizing spirit of public service devoted to self-aggrandizement and a quest for heroic stature. This new spirit of service and nationalism is doomed to failure, Shelley suggests, because it proposes a superior ideal for men to attain, but not for women. Her forwardlooking novel, set at the close of the twenty-first century, forecasts a destruction of 
English society if men are allowed to turn their backs on the role of protecting and identifying with the domestic center.

As a futuristic novel, The Last Man suffers from a failure to imagine the technical achievements to come in the nineteenth and twentieth centuries; the balloon flights over England, for example, seem comically inadequate to energize a twenty-first century setting. However, Shelley argues for social and political reformation modeled on ideals of public service concomitant with ideals of domestic service. In the coming decades Victorians would shape a modern national identity from a model of servitude Shelley presciently foresaw. The necessary reform of the public schools that would convert institutions of open rebellion and disorder into training grounds for a coherent Civil Service system was yet to occur. The Indian and Foreign Civil Service, like the Home Civil Service, operated through patronage and irregular allegiance, rather than a system of examination and discipline that would flourish later in the century. The Diplomatic Service, a holdover from the eighteenth century that was largely the domain of amateurs and independent envoys lacking adequate communications with the ambassador and Foreign Secretary, was just beginning between 1822 and 1827 to be reformed by Foreign Secretary George Canning into a Foreign Service that would be recognizable today. And the Military and Naval Services had yet to arouse public opinion and reform that would be needed to discipline and command a modern army. In addition to these institutional systems just beginning to undergo modernization, the networks of formal and informal associations that would create a public character of religious, business, scientific, cultural, educational, agricultural, political, and philanthropic societies to redefine and organized civil society were only inconsistently emerging from the late eighteenth century. ${ }^{2}$ This arena of public character was the focus of Shelley's futuristic novel.

In spite of Shelley's dismal projection of the abilities of such social and political organization to revive what she saw as a doomed society, the extent of her scope in imagining the development and reliance on such systems to reconstruct a modern society makes her vision remarkably prescient: she sees England on the cusp of a Victorian reformation centered squarely in a public ideal of national service. The sources of Victorian social reform are now historically reviewed as more diverse than Shelley's novel suggests. Patrick Brantlinger traces the early Victorian spirit of social reform to evangelical and humanitarian protest, governmental intervention to refurbish outmoded institutions, and Benthamite and Owenite schemes for improving mankind. This pattern gave way in the 1840s, he argues, to reform less dependent on legislation and bureaucratic social planning and more often typified by voluntary humanitarian activity. By mid-century, free trade and industrialism tended to promote a notion of progressive improvement through industry and self-help in a "cult of progress”(Brantlinger 1-2). But Shelley's novel looks down this road of coming social change and rejects reliance on economic and institutional action, instead embracing charity and individual involvement in a spirit of public service as the only means of surviving social upheaval. Her narrator Lionel Verney, witnessing the arenas of public duty, reports a new kind of male society devoting the individual to a career of public service arising from private loyalty and ideals of servitude based on the domestic arena. 
Mary Shelley was herself notably silent about explaining her plans for The Last Man in her letters or her journals. Only one letter survives to articulate briefly her intention in writing this novel. After having published her new book under the title, The Last Man, A Romance, by the Author of Frankenstein, she sent a letter to John Howard Payne, the actor and playwright, lamenting the public excitement elicited by the title of the book "because of the disappointment that must of course follow":

You can form no idea of the difficulty of the subject--the necessity of making the scene universal to all mankind and of combining this with a particular interest which must constitute the novel--If I had at the commencement fore seen the excessive trouble \& then (much worse) the state of imperfection in which partly for want of time I was obliged to leave it--I should never have had the courage to begin. (qtd. in Bennett 510)

That she sought "the universal" from her particular life shows up in the immense scope of the novel that ranges across philosophical arguments, parliamentary debates and schemes, imperial conquests, the French Revolution, class conflict, war, disease, emigration and, pervading all of this "public" concern, the state of the bourgeois family. ${ }^{3}$ That she associated her own private loneliness and sorrow with the servant, a wayward shepherd-boy who enters service as a private secretary at the opening of the novel and, at the close, returns to being a lone, wandering shepherd, indicates the distance she sought from her own gender and class identities to make her commentary more "universal” and public. As in her father's novel, Things as They Are; or, The Adventures of Caleb Williams, the class dimension in The Last Man allowed Shelley to reach a wider range of "all mankind" and transcend her "particular" and private circumstances. Perhaps she feared rejection from readers because their expectations, whetted by Frankenstein, might be disappointed in a novel so openly political. ${ }^{4}$

Anne K. Mellor has argued that Mary Shelley employed an apocalyptic vision of destruction in The Last Man as a way to settle her oblique criticism of Percy Shelley's insensitivity to the needs of his wife and children in his demanding and risky travels (150). Shelley's insistent moves across Europe that carelessly sacrificed his children's health had precipitated their early deaths, and the continued grief this caused Mary Shelley compromised her devotion to mourning her husband's memory. Left with only one child at Percy's death, Mary Shelley appeased her sorrow, Mellor argues, by writing The Last Man as a statement of her larger ideological commitment to the familial bond she saw as weakened by a division of labor on the basis of sex. This weakening is caused by the domination of masculine values in the public realm and the loss of a shared personal responsibility for the nurturance and preservation of human life in the private realm. Mary Shelley was strengthened in her grievance against Percy Shelley by an ideology of "female consciousness," defined by Temma Kaplan: "Female consciousness centers upon the rights of gender, on social concerns, on survival. Those with female consciousness accept the gender system of their society; indeed, such consciousness emerges from the division of labor by sex, which assigns women the 
responsibility of preserving life” (545). Mellor argues that from this essentially conservative ideology, Mary Shelley critiques the doctrine of separate spheres that defines the woman's role as the creator and preserver of human life. The bourgeois society presented by the novel fails to create and preserve life, a mistaken course, the novel suggests, that can lead to the extinction of all human life (Mellor 150-151).

Yet I assert this novel claims a more complex exchange across these realms that seeks to retain a viable male presence and commitment within the domestic realm while lamenting the options available for extending the female presence out into the public arena. Further, Shelley sees men removing the ideals of familial service from the home to recenter the state as the primary--and exclusively male--authority for social identification. Shelley examines notions of man's individual role serving a society in order to challenge prevailing assumptions that men can exchange domestic involvement for public service and empty the home of an equal partnership of men and women. The instrument Shelley employs to mediate this exchange is the figure of the servant poised between these two worlds. Verney is brought into the domestic arena only to persistently move out and away from it, employed first in diplomatic service before serving Raymond in the Greco-Turkish war, offering himself as a public servant in Parliament, and finally acting as home civil servant to a collapsing England. In each of these national duties--Diplomatic, Military, and Civil--he witnesses the failure of public man to successfully manage the far-flung problems of a nation removed philosophically from the ideals of cooperation and loyalty inherent in the most basic family unit. That he at last remains the only man alive, while all human institutions have been destroyed, suggests the utter failure Shelley saw in investing mankind with a hubristic ideal that divided the home and placed it in service to the state.

\section{The woman as servant in The Last Man.}

Shelley's thesis of political and domestic conflict is portrayed as the tension between the appeal of a public and active life that lures the man away from the family and the domestic peace and sovereignty that the woman offers to lure him back into the home. The opposing loci of service can be readily seen in the marriage of Lionel Verney's sister Perdita and Raymond, a marriage of love that at first seems superior to the political marriage he could have formed. Shelley suggests through Perdita that regardless of class, woman is always relegated to this servile status by her dependent position in marriage, a position that makes her subject to her husband and devoted to keeping him happy. The asymmetrical fulfillment of desires, however, ultimately satisfies neither party in marriage. In this dichotomy between men's and women's arenas Shelley announces one of her most persistent and complex grievances with domestic accord: how can the private sphere maintain a fluid reciprocity, much less analogous authority, with the public sphere if men move between the two at will, but women have "office" in only the private? For Shelley in this apocalyptic novel, the imbalance of power and the movement of the man out into an exclusively male public life lead in the end to the destruction of both worlds. 
What makes her portrayal of this struggle particularly acute in the second decade of the nineteenth century is the critique of the man's selfish removal from the domestic realm, a desertion that she shows through the servant-narrator as persistently sacrificing the welfare and security of the home to a desire for worldly adventure and individual selfimportance. In The Last Man, as in her Frankenstein five years earlier, foreign and political conquests and absence by men from the domestic arena signal doom for the private world. Raymond's neglect of the home is as destructive as Victor Frankenstein's belabored dalliance in Ingolstadt and untimely return to his family, too late to save the lives of his household.

At the same time, Shelley's novel critiques the formation of a singular "republican motherhood" that relegates the woman to a background status as maternal and invisible labor to the interests of the public man, who in turn elevates the principles of loyalty, faith, and self-sacrifice to nation, rather than to family. She rejects such maternal thralldom as absolving men of any private function and endangering the essential meaning of home. What Shelley proposes in the place of this unbalanced and untenable isolation of realms is a unified, continuous, and mutually constitutive declension of roles, with women and men, domestic and national, merging into each other in shared alliance. That her novel is ultimately dystopian reveals a cynical and aggrieved conviction that the nineteenth-century imagination--as formulated by the men who held public sway-was not prepared to accommodate such an harmonious resolution as it fueled the emerging spirit of national expansion. Raymond's contraction of the plague and death in the Greek revolutionary war suggests Shelley's rejection of a vainglorious nationalism that leads men away from the center, rendering the home helpless to the arbitrary, mysterious, and dangerous forces that invade from outside.

Shelley's defense of the home as familial, rather than English national, identity anticipates and denies an ideology of nationalism that was in only the earliest stages of a movement that would define the coming Victorian era. Underlying her vision of domestic vulnerability and imperial engagement is the growing awareness that a future female monarch would assume the throne of England while continental Europe oscillated between disorderly factions. On the domestic front, England was slowly realizing the enormous social engagement that would be required to bring the country into a full industrial and productive condition. Social reform would require a major overhaul of the English cities and countryside: systems of health, sanitation and education of the poor were yet to be developed; railroads and transportation systems to move the materials and products of manufacturing would have to be built to meet the demands of an expanding nation; and voting rights were yet to be extended beyond freeholders. A spirit of public organization and involvement would be necessary to accomplish the task of modernizing the nation if the turbulence of the continent was to be forestalled in England. The fact that a female monarch would propose a new, more ambiguous blurring of distinctions between the private and the public, the family and the state, is foreshadowed in Shelley's novel that remarkably predicts the tenor of public service that would motivate the century's spirit of achievement. Unlike Perdita, the reluctant public wife and private "servant" to Raymond, Victoria would have to negotiate the territory of public wife and public servant to England. Shelley's vision of 
a troubled scheme transforming the private "offices" of the domestic into public service to the nation is most fully realized in the figure of Lionel Verney, the servant "born again" into a new and "higher" servitude to his nation.

\section{Republican motherhood.}

Lionel Verney begins narrating The Last Man with an extended explanation of the loss of his father and familial protection: the senior Verney, a court favorite of the king, had lost his position as royal servitor through raucous living, gaming debts, and the dexterous manipulations of the jealous queen, who resents her husband's ignoble affiliation. The king, over the queen's objections, had later reformed the monarchy into a parliamentary republic and stepped down from power, but not before Verney had retired to the countryside, outcast and apparently forgotten. Impoverished, the former royal servant had fathered two children before dying, leaving young Lionel Verney and his sister orphans upon their mother's subsequent death. Unprotected and resentful of his loss of paternal inheritance and honor, Verney had at a young age gone out to service, employed by a farmer as a shepherd. ${ }^{5}$ As the novel opens he is roaming the countryside with other shepherd-boys, growing increasingly wild and dissolute and setting aside his duties for a more independent spirit: "I wandered among the hills of civilized England as uncouth a savage as the wolf-bred founder of old Rome” (9). In his discontent, the young Verney echoes the increased ranks of uneducated, disaffected young males in England who resisted confinement to menial and subservient labor but who lacked the skills and sponsorship to fit into a "civilized," modernizing nation and Empire.

From this precarious state of "savage” discontent and shapeless employment, Verney is discovered and reformed by the ex-king's son into a cultivated and public servant, reborn figuratively into a more productive and worthy version of his father's service to the old king. In his habit of stealing game and tyrannizing rustics, Verney at sixteen learns that the nearby estate of the former royal family is poised to receive the deceased king's heir, the Earl of Windsor, Adrian. Their destinies joined by their fathers' bond of friendship ("We were born to be friends to each other") formed in an old master-servant relationship, Adrian suggests the two boys' births were "united” by male paternal consortium ("the hereditary bond of friendship"), like twins produced from a union of male camaraderie and later divided by class--and the queen's--intrusion. Their meeting on the grounds of the estate signals the reunification of patriarchal sovereignty and, concomitantly, a spiritual reunification of father and son and fraternal loyalty through a natal alliance undisturbed by female involvement. It is a biological reconstitution of patriarchal authority that Adrian's offer proposes.

This fraternal birth is notable for its elision of the mother, here cast out as a disruptive intruder who dislodges male loyalty and lineage. In her stead, Adrian acquires the attributes of a benevolent, maternal woman who brings life to the wayward Verney and returns him to the domestic fold. In the process, the contrast of class fortunes is transcended through a specifically feminized and maternal discourse now adopted by the male protagonists. Adrian's refinement and “sweet benignity” quicken the nascent 
life in the "savage” Verney who heeds Adrian's call: “[His] thrilling voice, like sweetest melody, awoke a mute echo within me, stirring to its depths the life-blood in my frame" (17). Like a maternal promise of new life, Adrian's persuasive appeal to Lionel Verney addresses the desire to be born again into the mother's protective society. The call simultaneously acts as an appeal to the base and "savage" lower orders to accept a parental model for authority. ${ }^{6}$

This figurative adoption, deployed through royal, matriarchal authority, is suffused with a parallel language of imperial acquisition that gives muscle to the allure of domesticity. Adrian's "active spirit of benevolence" conspires to complete the "conquest": "[Adrian] was all mind. . . and it would have conquered his strength; but the might of his smile would have tamed an hungry lion, or caused a legion of armed men to lay their weapons at his feet” (18). Like the hungry lion, a reference to the animalistic appetite and exotic otherness perceived to define the colonial native "savage," Verney cedes the conquest, and in doing so becomes simultaneously colonized and feminized in a language of imperial chauvinism that reinvests his birthright as native subject: "As he spoke, I felt subject to him ... The trim and paled demesne of civilization, which I had before regarded from my wild jungle as inaccessible, had its wicket opened by him; I stepped within, and felt, as I entered, that I trod my native soil" (18). Shelley proposes in this seductive conquest a right of imperial authority if it aligns the project of "civilizing" the unruly "savage" with a nobler, feminine spirit of familial inclusion. She suggests that a maternal authority conquers through desire and allure, rather than through physical strength and brutal confrontation. But Shelley also suggests here that the lower orders of England, the native subjects disordered and adrift, can be subjugated through a patriarchal language that replicates the colonial parent-child model of control.

The languages of imperial and maternal authority conspire to generate a new power that infuses Verney with fervent passion and inspiration drawn from the family romance. Adrian seems to Verney as a gentle, benevolent mother, giving him new life, "mastering" his soul, and pulling him up into the "intellectual and moral nature" that defines a new kind of ruler, made powerful through absorbing the female and maternal: “'This,' I thought, 'is power! Not to be strong of limb, hard of heart, ferocious, and daring; but kind, compassionate and soft.' ... I was born anew ... I was as a child lisping its devotions after its mother, and my plastic soul was remoulded by a master hand, which I neither desired nor was able to resist" (19-20). Before, a "savage" and brutal animal, Verney is now "born anew," "humanized" and domesticated by the "master hand" that assumes the role of maternal provider and preserver of life to feed his appetite for human meaning and definition. Like a "devoted" child Verney accepts a subject position as the servant-child to the stately mater/master; the qualities of maternal guidance and feminine benevolence are portrayed as an ideology of rule that controls through a new kind of maternal mastery: "Sometimes my lawless mood would return, my love of peril, my resistance to authority; but this was in his absence; under the mild sway of his dear eyes, I was obedient and good as a boy of five years old, who does his mother's bidding” (24). The domestic power of the mother is isolated as a method for ruling the wayward subject-child, exploiting the parental authority-- 
historically paternal--that controlled the household servant to now manage the unruly and disaffected lower classes of men through desire for the maternal.

The infusion of feminine imagery into the otherwise patriarchal unification of Verney and Adrian suggests that Shelley saw the most complete parental and authoritative bond as one merging male and female together in a rhapsodic and nurturing force that controls through a natural human appetite for familial inclusion. In Adrian she blends the two genders, not into one androgynous figure but into a combination of male/imperial and female/maternal authority, to propose the ideal bonding of parental love that unites father, mother and child in one organic, protective unit. At the same time, this parental model reconstructs a feminized, imperial version of the colonized subject-child in the master-servant relationship. Shelley portrays a Mother England who adopts and guides her native lower classes as a domestic empire corresponding to her imperial Empire.

Under this reformation of his social conscience and welfare, Verney discards his rough profligacy to become reborn as the collaborating, conquering Englishman, a colonial subaltern fully complicit with an imperial spirit: "I felt as the sailor, who from the topmast first discovered the shore of America; and like him I hastened to tell my companions of my discoveries in unknown regions" (21). Borrowing a grammar of colonial conquest, discovering new shores, new regions, new countries, Verney portrays his "transmigration" as an ascension from the physical, the low and savage, the brutal and animal, "rough as an untrod wild in America" (24), into the upper realm of spirit, intellect and moral consciousness, elevating the mind over the body as a noble, imperial challenge. In the process, Shelley argues, he leaves behind his position as a lowly farm servant to commit himself to a higher, more patrician form of servitude to the Earl of Windsor and the British Empire.

\section{In service to England.}

Shelley's project to reclaim the lost servant/subject wandering aimlessly through England does not, for all its domestic and maternal association, envision a reentrenchment in the private arena. By the 1820s England was not directing its men of the lower orders back into household service. Instead, Verney enters into a process reconfiguring the low male servant as a new kind of public servant, raised up to apply the same principles of loyalty and subservience in the worldly arena. Having conquered and tamed Verney's spirit, Adrian sends his new charge out into a "necessary Apprenticeship" of diplomatic service in Vienna, where Shelley criticizes the boundless and naive passion that such diplomatic service generates, again borrowing from a language of conquest to inspire Verney with ungainly heroic proportion:

Life is before me, and I rush into possession. Hope, glory, love, and blameless ambition are my guides ... During my journey I might dream, and with buoyant wings reach the summit of life's high edifice. Now that I am arrived at its base, my pinions are furled, the mighty stairs are before me, and step by step I must ascend the wonderous fane-- (25) 
The description is suffused with images of exploration and conquest, naively inflated in visions of oceanic voyages to golden shores, summits and heights to be gloriously possessed, and the heroic spirit of adventure that pervades this passage. Verney imagines himself now the conquering hero, drawn to his mission with a spiritual fervor recalling classical heroic asceticism that over-reaches the more pedestrian challenges of his service. The passage rings with the spirit of imperial expansionism that yoked nineteenth-century principles of national conquest to those of individual sacrifice and heroic assertion.

But Shelley undercuts this self-congratulatory heroism in the undisciplined riot that awaits Verney in the pleasures and excess of Vienna. The leap from rural, domestic subject to imperial servant is imperiled because it removes the artless man from the familiar and humble landscape that was his true home. In the "giddy whirl" of this gay city and unable to sustain a sense of duty and purpose, Verney succumbs to the seductive manners of the worldly men and women around him, and he once again reverts to a lawless appetite for hedonistic pleasure that is now merely an eroticized version of his former animalism in the wilds of the English countryside: "The mere flow of animal spirits was Paradise, and at night's close I only desired a renewal of the intoxicating delusion. The dazzling light of ornamented rooms; lovely forms arrayed in splendid dresses; the motions of a dance, the voluptuous tones of exquisite music, cradled my senses in one delightful dream” (26). This passage overturns the earlier rebirth and maternal coddling of Verney, so that now he is "cradled" in an orgiastic, feminized exoticism and allure of the Eastern harem, ornamented and splendid, voluptuous and exquisite in its seductive intoxication. Associating the feminine images here with a specifically orientalized sexual entrapment, Shelley contrasts this passage to the benevolent maternal seduction that had led Verney into this new career of noble servitude. The comparison linking imperial conquests from both the West and the East suggests that both transformations draw a false veil of feminine allure to disguise what is at heart a masculine and political subjugation.

As in the earlier seduction, the chimera of womanliness, here distorted as sexualized rather than maternal seduction, comes wrapped in a concomitant language of conquest, but now the imperial dreams are disappointed and broken. Verney's training in imperial service, so buoyantly anticipated from England on his journey out, dissolves into a stupor of melancholy that exposes the shallow, treacherous nature of the conquest reverie:

The mind flags beneath the weight of thought, and droops in the heartless intercourse of those whose sole aim is amusement. There is no fruition in their vacant kindness, and sharp rocks lurk beneath the smiling ripples of these shallow waters ... My flagging spirits asked for something to speak to the affections; and not finding it, I drooped. (26)

Verney's "flagging” mind and spirit contrast and corrupt the "wonderous fane" that had earlier unfurled his imagination, and the "golden sands" and oceanic conquests of his 
dreams turn into sharp rocks that lure him to failure. As with the maternal fantasy that mutated into a veil of sensual deception, the delusion of imperial command founders when isolated from the "affections" that had inspired it.

After his two-year apprenticeship in Vienna, Verney returns to English shores like a chastened child returning to its mother: "Farewell to courtly pleasure; to politic intrigue; to the maze of passion and folly! All hail, England! Native England, receive thy child!" (28). The jingoistic patriotism that stirs this enthusiasm mocks the maternal love that had generated Verney’s transformation. Shelley suggests that the core of parental and familial obligation cannot be cheaply bargained for or sustained if it is withdrawn from the practice of private familial service that dotes on it.

\section{The ob/servant corps.}

Verney's service in London is marked by his oscillation between the fractious, acrimonious realm of public governance and the felicitous respect of private friendship and the home. Shelley poses Verney as a kind of benign and helpless witness mediating between these two worlds in order to make her argument that the separation of duties and authority into rigid gender-based arenas undermines both realms. As a marginal outsider to both the public and the private, Verney is situated as the observing figure who always remains detached and selfless, a reporter of other people's lives and actions, content to filter the experience of life through obedience and to defer public acclaim--in effect, the perfect civil servant.

Verney's initiation into English public life and the intrigues of Parliament is expedited through his father's history of service. As former secretary to the Viennese ambassador, Verney now can enter behind Raymond into the fashionable and political circles of London, which appear to him as on the verge of violent civil war. But the refractory discourse of politicians baffles Verney, who notes the "cordial politeness and even friendship of the hostile leaders when they met in private society. I was from a thousand motives induced to attend minutely to the course of events, and watch each turn with intense anxiety" (34). Shelley suggests that the manners and goodwill of private relationships allay the "destructive flames" of public confrontation and debate. Juxtaposing London life and the public debates with visits to his country retreat with his sister, Verney physically moves between the two worlds to present a corresponding argument for the ennobling powers of the domestic and private world: at Windsor with his sister, he fancies himself "in a fairy retreat untainted by and inaccessible to the noisy contentions of politicians and the frivolous pursuits of fashion” (35). Shelley intermingles the two realms throughout her chapters on public and governmental affairs as if to suggest that she sees no way to imagine how a public life can be defined or composed without an attendant and restorative private society.

Verney's role, however, remains throughout one of quiet and watchful service to the politician, with Raymond scheming to restore the monarchy and become sovereign himself. Verney's role is to report on the rise of Raymond as a civil servant, one whose plan for turning London into a powerful new cultural center calls for urban expansion, 
new construction, and education for the poor. His plans read as a fantastic litany of nineteenth-century social, civic and industrial reform imagined by a spirit of philanthropy and enterprise that shaped the Victorian public servant: "Canals, aqueducts, bridges, stately buildings, and various edifices for public utility, were entered upon; he was continually surrounded by projectors and projects, which were to render England one scene of fertility and magnificence; the state of poverty was to be abolished . . . disease was to be banished; labour lightened of its heaviest burden" (76). Shelley's portrait of an English social revolution revitalized "spontaneously" reveals a utopian dream that impossibly resolves "every want” mechanically, with material management of the population superseding emotional and spiritual fulfillment.

The monumental reach of this project is revealed as vacant and self-aggrandizing. Coveting the title of "benefactor of his country" (76), Raymond seeks an architect to design a national gallery with an edifice that would serve as the "great ornament of his Protectorship." In his reach for this temple to his glory, like Verney before him reaching to "the summit of life's high edifice" only to end in despotic enchantment, Raymond is lured into his downfall. His former lover Evadne, a Greek princess, secretly submits a plan for the national gallery based on "the edifices which she had seen in the east” (83) and seduces Raymond into an affair that destroys his marriage to Perdita and ends his reign as public protector (84). The public temple that he would build to his own municipal glory is corrupted into a secretive private temple of delirium, creating an isolated world for Raymond and Evadne that mocks and erodes his marriage to Perdita. The lovers' "wall between them and the world" becomes a false and distorting barrier severing the public and private spheres, separating husband from wife and man from his own heart. Shelley shows this corruption to be ultimately destructive to the task of replenishing the social structure as well, as Raymond's public life collapses in the wake of his private life.

Dividing his domestic life into a secret privacy with Evadne and a public image with Perdita, Raymond precipitates his own downfall and abdicates his role as public servant, acknowledging his lack of self-rule to the aristocratic Adrian: "You the good, the wise, the just, may rule all hearts. But I perceive, too soon for my own happiness, too late for England's good, that I undertook a task to which I am unequal. I cannot rule myself. My passions are my masters; my smallest impulse my tyrant” (109). Shelley here takes to task what she sees as the egotism of the man who would master the world but who cannot rule himself and will not rule his home. The aristocratic Adrian is proposed as the more natural and fit administrator of public welfare, a man who knows how to control himself as well as others.

At the same time, Shelley sees the docile wife Perdita as complicit in eroding the substance of her marriage. While Perdita had granted him masterly authority in the home, she had also built the same subservience into their public life: "[Perdita's] whole existence was one sacrifice to him" (84). Shelley admonishes the woman who foregoes her own life and an active marital alliance in favor of acquiring and holding onto the “distinguished hero of the age," as if her husband's public image were adequate compensation for a private and lonely discord. With the collapse of marriage, Perdita is 
left stranded when Raymond turns to military service and glory commanding a division of the army in Greece's war: "He, she thought, can be great and happy without me.

Would that I also had a career! Would that I could freight some untried bark with all my hopes, energies, and desires, and launch it forth into the ocean of life--bound for some attainable point, with ambition or pleasure at the helm” (117). The possibilities open to the public man seem a ceaseless flow of movements that carry him further from the home while leaving the wife deserted: "like Ulysses" Perdita mourns, "I sit at the water's edge and weep” (117).

Raymond's heroic military career, however, also collapses under the crushing weight of destruction and political disenchantment. When Verney goes to Greece to search for the missing warrior, Raymond admits his ambivalence to Verney: "I am but half a soldier; I love the renown, but not the trade of war” (133). Verney briefly takes up the cause of the war in order to aid his embattled friend, serving as Raymond's obedient attaché; but when Raymond is killed in Constantinople, Verney suffers his final disillusionment with imperial glory: "The excitement which had hitherto sustained me was lost; as a building, whose props are loosened, and whose foundations rock, totters and falls, so when enthusiasm and hope deserted me, did my strength fail” (146). This moment seems a full return on the dream he had held of reaching "the summit of life's high edifice" and ascending the "mighty stairs" of the "wonderous fane" as a young diplomatic servant going out to the east. In his disillusionment, Verney sees the summit as merely a pile of collapsed monuments to a transient glory that destroys mankind. He turns his back on worldly ambition and retreats to England and domestic security:

How unwise had the wanderers been, who had deserted its shelter, entangled themselves in the web of society, and entered on what men of the world call "life,"--that labyrinth of evil, that scheme of mutual torture. To live, according to this sense of the word, we must not only observe and learn, we must also feel . . . Let us live for each other and for happiness; let us seek peace in our dear home, near the inland murmur of streams, and the gracious waving of trees, the beauteous vesture of earth, and sublime pageantry of the skies. Let us leave "life," that we may live. (158)

Shelley criticizes the ambition of men--even when ennobled by a glorious cause--who seek "sublime pageantry" in worldly affairs and overlook the victory of merely living. Through Verney she rejects the ambitious hopes that pull men from a passive and observing spectatorship into the schemes of action that destroy them. But at the same times her cynicism that this "labyrinth of evil" can be successfully surmounted overwhelms her enthusiasm for a new domestic man: a few days before Verney lands at Portsmouth, an American built vessel sailing from Philadelphia brings the plague to English shores, revisiting the colonial "mother country” like a wayward child. 


\section{The unglorious civil servant.}

Contrasting Raymond's failed effort at public enterprise and heroic glory is Lionel Verney's self-effacing, modest commitment to domestic, local service that seeks reform and defense through communal and familial unity. Against the catastrophic collapse approaching with the plague, Verney launches a judicious management of resources to fortify the people of the countryside. Offering a cooperative model of local governance as the ideal political plan, Shelley portrays Verney as the exemplar civil servant, loyal and self-sacrificing, remaining close to the family to rally the community and organize against destruction. When the plague that ravages Greece and the eastern empires enters into Europe, English manufacturing structures falter in the collapse of trade. The colonies that had supplied the nation with materials and served as a repository for "any over plus of population” no longer offer relief for English commerce, while starving emigrants from without surge into the last country preserved from disease. The uncompromising portrait Shelley draws of social collapse reveals her fear that English government has extended its reliance on global resources and lavish empire-building at the expense of local systems rooted in communal and familial guardianship. It is only through the spirit of voluntary service, not to the glorious cause but to the mundane, that confusion can be allayed and order restored.

Verney's service to the community is portrayed as a natural outgrowth of his humble and feminized demeanor. Against the ravages of the plague, he offers simple, household values that echo the manuals of domestic management: "Remember that cleanliness, sobriety, and even good-humour and benevolence, are our best medicines" (178). That these prescriptions do not, in the end, save England from the coming debacle suggests Shelley's belief that the invasive malignity of grand illusions has terminally eroded public endeavors. Verney proposes a modest labor of charity and good-will as the framework for community that could have sustained the country if it had been adopted earlier.

Verney's lowly exertions are produced as noble and worthy accomplishments for the public man because they emanate from familial loyalty and uncommon love for his wife. Rallying the expanding community around the Windsor estate, Verney becomes a local figure of common wisdom and diplomacy, attracting the younger members of the community who seek out his advice. Opening the halls at Windsor to the growing ranks of the populace living in the parks surrounding the castle, he offers them encouragement, hope, and practical counsel, transforming himself into a community leader. His ability to organize resistance comes directly from his close ties to his family, not from political ambition: "This feeling of universal misery assumed concentration and shape, when I looked on my wife and children; and the thought of danger to them possessed my whole being with fear" (180).

If Shelley portrays Verney as the model of civil service and domestic virtue, she sees his familial analogue in the national leadership of the aristocratic--and maternal-Adrian, who steps in to resume rule of the ailing country. The reinstitution of aristocratic rule through the royal heir, effectively ending the republican experiment in 
England, suggests Shelley's belief that the strife caused by men maneuvering for public acclaim distracts from the real business of running a country. Shelley rejects republicanism as a weak form of government that opens the country to opportunism and selfishness, as seen in the republican Popular Party leader, Ryland, who deserts his role of leadership when his personal safety is threatened by the plague. The rule of the nation, Shelley asserts, should rest in the nobility of a monarchy passed down through familial inheritance. Adrian, accepting his role as leader, echoes the doting language of maternal rapture that had first awakened Verney to public service:

This is my post: I was born for this--to rule England in anarchy, to save her in danger--to devote myself to her. The blood of my forefathers cries aloud in my veins, and bids me be first among my countrymen. Or, if this mode of speech offend you, let me say, that my mother, the proud queen, instilled early into me a love of distinction ... But now my mother, or, if you will, my mother's lessons, awaken within me. (185)

Adrian, who had once served as Verney's maternal savior, becomes himself the "child lisping its devotions” after its Mother-England. To him is relegated the authority to preserve the nation. To Verney is assigned the corresponding duty to protect the home and the family, a duty granting the private man authority as the analogous center of domestic rule mimicking national rule. Mother-England and the domestic mother are elevated to an idealized womanly status to whom men devote their service.

Shelley does not, however, propose this maternal service as an ideal of public service because it narrowly isolates the woman. Adrian instructs Verney to turn to his wife Idris as the core of national meaning, value, and possession that ultimately reflect back onto the public man (185). But Idris is portrayed as Verney's “divine” woman, a "poet's dream," a "carved goddess," a “pictured saint stepping from the canvas"_-in short, an idealized Angel in the House (189). Shelley shows her domestication as suffocating and, ultimately, destructive. Verney encloses her in their domestic circle, restraining her activities--her "thoughtless enthusiasm" devoting herself to the care of the sick and helpless (199)_-and directing her focus wholly into supporting his private world: "I checked her; and she submitted to my rule. I told her how the fear of her danger palsied my exertions, how the knowledge of her safety strung my nerves to endurance. I shewed her the dangers which her children incurred during her absence; and she at length agreed not to go beyond the inclosure of the forest" (199). This suffocating enclosure and devotion to her husband is shown as undermining the "vital principle" of her own health and life, as she slowly is consumed by disease and worry. Shelley shows her position as a double bind of ceaseless work that requires her to "throw a veil" over the signs of fear that consume her (219).

Shelley critiques such control of the wife as contrary to life continuance itself. To Verney, the signs of Idris' consumption are laid to the "over active life within her" that "deprived her limbs of strength" (231), as if she contained within her some fatal disposition to exceed an appropriately feminine domestic passivity. But Shelley opposes this selfish suppression of the woman's desire for an active and public life; when Idris 
finally succumbs to exhaustion and disease, Verney doubts the wisdom of isolating her from the world and from her own desires: "I often wished that I had permitted her to take her own course, and engage herself in such labours for the welfare of others as might have distracted her thoughts. But it was too late now" (231). Like Perdita isolated from commerce in the larger world, enclosed within the stifling loneliness of private life and locked out of the public realm her husband inhabits, Idris cannot survive solely as a domestic ideal waiting while the public man serves himself up to the country.

\section{The lost family.}

That Shelley shows Verney's world as one unable to sustain any family of man, even a Last Family, argues for a rejection of the course of nineteenth-century society and the privatization of the domestic realm as an isolated female enclave subjected to some higher, more noble duty to the public realm. Verney's desolate longing for companionship as he faces life alone serves as a tortured imprisonment that echoes the isolation of the private home. With all of the physical world at his command, Shelley suggests, the mastery of the public arena is empty and ultimately meaningless.

If the nineteenth-century man seeks to offer his services primarily to public achievement and civic duty, the price, according to Shelley, will be the destruction of the underlying foundation of familial society. She reserves her ideals of service for the private realm, where the most "graceful and heroic" forms of "devotion and sacrifice of self" can be enacted only in a cooperation of men and women working together. The only separation of labor that Shelley can accept remains inevitably tied to a mutual and "graceful submission" to homely duty, a submission that jealously covets service to the ancient patriarchal bonds that had held families together. Failing this commitment, humanity retreats into the Last Man to serve out a sentence of nomadic and barren isolation, wandering across the hollow empire of the public realm. Shelley's warning that this ideal of loyalty and sacrifice to the private home arrives too late to save England is a dismal, forbidding charge to level at a century that would relish public service and achievement. 
Works Cited

Bennett, Betty T., ed. The Letters of Mary Wollstonecraft Shelley, Volume I. Baltimore: Johns Hopkins UP, 1980. Print.

Brantlinger, Patrick. The Spirit of Reform: British Literature and Politics, 1832-1867. Cambridge: Harvard UP, 1977. Print.

Davidoff, Leonore. "Mastered for Life: Servant and Wife in Victorian and Edwardian England.” Journal of Social History 7 (1974): 406-28. Print. http://dx.doi.org/10.1353/jsh/7.4.406

Hunt, Lynn. The Family Romance of the French Revolution. Berkeley: U of California P, 1992. Print.

Jones, Frederick L., ed. Mary Shelley’s Journal. Norman: U of Oklahoma P, 1947. Print.

Kaplan, Temma. "Female Consciousness and Collective Action: The Case of Barcelona, 19101918.” Signs 7 (1982): 545-66. Print. http://dx.doi.org/10.1086/493899

Mellor, Anne K. Mary Shelley: Her Life, Her Fiction, Her Monsters. New York: Methuen/Routledge, Chapman and Hall, 1988. Print.

Shelley, Mary. The Last Man. 1826. Ed. Hugh J. Luke, Jr. Introd. Anne K. Mellor. Lincoln: U of Nebraska P, 1993. Print.

Sterrenburg, Lee. "The Last Man: Anatomy of Failed Revolutions.” Nineteenth-Century Fiction 33 (1978): 324-47. Print. http://dx.doi.org/10.2307/2933018

\footnotetext{
${ }^{1}$ See, for example, her letter to Maria Gisborne on January 12, 1820, in which she talks extensively of "our most detestable governors" and wonders, "Athens flourished but just before the despotism of Alexander-Will not England fall? I am full of these thoughts ... " In a letter to Marianne Hunt on March 24, 1820, Mary Shelley goes on at length about Castlereagh's
} 
reactionary policies at home and abroad, musing finally, "You see what a John or rather Joan Bull I am so full of politics-”" (Bennett 124, 138).

${ }^{2}$ For an analysis of philanthropic societies and voluntary associations in this period, see Davidoff and Hall, Family Fortunes: Men and Women of the English Middle Class, 1780-1850. Chicago: U of Chicago P, 1987. Print. Especially Chapter 10, 416-450.

${ }^{3}$ Lee Sterrenburg also sees in Shelley's novel a political critique of the prospects of politics and empire that was popularized in the decline and fall theme following Napoleon's defeat in 1815, noting that The Last Man is "probably the most expansive in its allusions to political writings and events from the era of the French Revolution, the Napoleonic Empire, and the Greek revolution against the Turks during the 1820's.” Sterrenburg sees Shelley's novel as a survey of political positions and metaphors espoused by her parents' generation that Shelley rejects as hopeless revolutionary symbols(Sterrenburg 324-47).

${ }^{4}$ Shelley defended herself later in life against accusations that her views were politically conservative and that she was only lukewarm to "the good cause," which she defined as "the cause of the advancement of freedom and knowledge, of the rights of women, \&c." She acknowledged that she was "not for violent extremes, which only bring on an injurious reaction." But she asserted, "At every risk I have befriended and supported victims to the social system; but I make no boast, for in truth it is simple justice I perform; and so I am still reviled for being worldly.” In spite of The Last Man, Shelley was apparently unable to comfortably assume a political posture in her lifetime independent of her identification with her father and husband. (Jones 204-06).

${ }^{5}$ Mary Shelley's depiction of shepherding as domestic service is consistent with the historical status of servants at that time in the century; rural demographics for the first part of the nineteenth century typically included farm servants as a significant part of the occupational group of "domestic service" (Davidoff 409).

${ }^{6}$ For an extended study of the implications of the family romance in the politically turbulent years surrounding the French Revolution, see Hunt, Lynn. The Family Romance of the French Revolution. Berkeley: U of California P, 1992. Print. 